\title{
Capitalization and the Voucher: \\ An Analysis of Precinct Returns from California's Proposition 174
}

\author{
Eric Brunner, San Diego State University \\ Jon Sonstelie, University of California, Santa Barbara \\ Mark Thayer, San Diego State University
}

June 15,2000

For helpful comments on a previous draft of this paper, we are grateful to Timothy Goodspeed, Philip Graves, Terra McKinnish, Richard Romano and seminar participants at the Air Force Academy, the University of Colorado, and the University of California, San Diego. 


\section{Capitalization and the Voucher:}

An Analysis of Precinct Returns from California's Proposition 174

In 1993, Californians voted on a statewide voucher initiative, Proposition 174. We hypothesize that homeowners in good public school districts should have perceived the voucher as a threat to their property values and thus should have voted against the initiative. To test this hypothesis, we analyzed the relationship between precinct returns on Proposition 174 and the housing price premium for public school districts. We found that voters in districts with high premiums were less likely to vote for the voucher, confirming our hypothesis. 


\section{Introduction}

Among the many proposals to reform public education, the most fundamental is surely the voucher. The voucher would subsidize private elementary and secondary schools, making high-quality education in the private sector more affordable for families. Proponents of the voucher also argue that, by stimulating competition, the voucher would improve the quality of public schools. Through both avenues, the voucher would essentially lower the price of educational quality and consequently should have the political support of families who demand high-quality education.

While consumers of a good are generally better off when the price of that good falls, we believe the voucher is not necessarily in the best interests of families who demand high-quality education. In particular, we hypothesize that many such families may perceive the voucher as a threat to their property values and thus be opposed to it. The basis for this hypothesis is the market for public school quality. The typical metropolitan area has many school districts, which differ considerably in quality. Families select districts through their choice of residence, and housing prices therefore reflect the quality of a district's schools. Families who demand a highquality education for their children buy houses in good public school districts and pay a housing price premium for doing so. By subsidizing private competitors, a voucher would decrease this premium, imposing capital losses on homeowners in those districts. These losses are an ironic consequence of the voucher, ironic because the voucher aims to reduce the price of high-quality education, yet may adversely affect families who have already chosen such an education.

Perhaps that explains why an idea that has been around for so long has never been fully implemented. The closest the voucher came to full-scale implementation may have been Proposition 174, the 1993 voucher initiative in California. Under the initiative, the state would 
provide parents $\$ 2,600$ for every child enrolled in a private school. The initiative lost by a margin of 2 to 1 . Was the vote on Proposition 174 influenced by homeowners' concerns about the capitalized value of their public schools? Did capitalization defeat the voucher? We address these questions in this paper. We collected voting returns on the voucher initiative for 2,174 precincts in Los Angeles County. We also estimated housing price premiums for each of 73 school districts in the County. Combining these two elements, we determined whether the percentage voting yes in a precinct was related to the housing price premium for the precinct's public schools. As hypothesized, we found that there was a negative, statistically significant relationship between those two variables. Furthermore, we found a sizeable coefficient on the relationship between premiums and returns, indicating that the capitalization of school district quality was a significant factor in the defeat of Proposition 174.

\section{The Effect of the Voucher on Housing Values}

The value of a community's houses reflects the quality of its public schools. Because the voucher opens new options for families, it may affect this relationship between value and quality. Nechyba (2000) analyzed this issue in the context of a computable, general equilibrium model. He found that the voucher would increase housing values in communities with poor public schools and decrease values in communities with good schools. In this section, we present a simple, partial equilibrium model that illustrates the logic behind this finding.

Consider an area comprised of two communities. The communities are identical except in the quality of their public schools. Community 1 has good schools, and Community 2 has poor schools. Each community has $n$ houses, and all houses are identical. In Community 1, houses rent for $r_{1}$; in Community 2, the rent is $r_{2}$. 
Because Community 1 has better schools, its houses have higher rents. The difference in rent between the communities is the price to a family of an increase in school quality. A family may also purchase educational quality by sending its children to a private school, which we assume to be comparable in quality to public schools in Community 1. Private school tuition is denoted by $t$. If a family chooses private school, it will also choose to live in Community 2 where the rent is lower. Thus, a family has two alternatives for purchasing educational quality: live in Community 1 and send its children to public school, or live in Community 2 and send its children to private school. The first alternative has a price of $r_{1}$, and the second a price of $r_{2}+t$.

This model has two types of equilibria. In one type, families don't send their children to private schools because it is cheaper for them to obtain a high-quality education by living in Community 1 and sending their children to public school. In the other type of equilibrium, some families in Community 2 send their children to private school, which implies that the price must be the same for the two alternatives for purchasing educational quality. That is, in this equilibrium,

$$
r_{1}=r_{2}+t
$$

We focus on this equilibrium in what follows.

Equilibrium rents depend on the demand for housing in the area. We separate that demand into two parts. The first is a demand for high-quality education, denoted by $f_{h}\left(r_{1}, r_{2}\right)$. It is the number of families who demand to live in the two-community area and send their children to a high-quality school. The second part is the demand for low-quality education. It is the number of families who, given rents, demand to live in Community 2 and send their children to 
public school. It also consists of families without children who have no reason to pay a premium to live in Community 1 . We denote this demand by $f_{l}\left(r_{1}, r_{2}\right)$.

The demand for high quality can be accommodated in either Community 1 or 2 . However, the demand for low quality can only be accommodated in Community 2. Thus, in equilibrium,

$$
\begin{aligned}
& f_{h}\left(r_{1}, r_{2}\right)+f_{l}\left(r_{1}, r_{2}\right)=2 n, \text { and } \\
& f_{l}\left(r_{1}, r_{2}\right)<n .
\end{aligned}
$$

Conditions (1), (2), and (3) characterize equilibrium.

Because the voucher is a subsidy to private school tuition, it is equivalent in this model to reducing private school tuition, $t$. A decrease in tuition increases the rent in Community 2, the community with poor schools, and decreases the rent in Community 1, the community with good schools. Equation (1) implies that the difference in rents between the two communities must equal private school tuition. A decrease in tuition must therefore decrease the difference in rents. One way to accomplish this would be to increase rents in both communities, increasing the rent in Community 2 more than in Community 1. However, increasing rents in both communities would decrease total demand for the area and would thus be inconsistent with Equation (2). Similarly, decreasing rents in both communities would be inconsistent with Equation (2). Thus, the only way to decrease the difference in rents and maintain equality between demand and supply is to increase the rent in Community 2 and decrease the rent in Community 1.

These changes in tuition and rents have different effects on renters in the two communities. Renters in Community 1 are in the same position as the renters in Community 2 who send their children to private school. Both sets of families have opted for high-quality 
education, which is now cheaper, making them better off. Renters in Community 1 are better off because their rent is lower. For renters in Community 2, rent is higher, but this increase is more than offset by the decrease in tuition, yielding a net decrease in the price of a high-quality education.

The effect of the voucher is different for renters in Community 2 with children in public school and for those without children. Renters in Community 2 without children are worse off because they pay a higher rent. Renters in Community 2 who send their children to public school are in a similar position. If they continue to send their children to public school, they are worse off because their rent increases. However, they may now choose the private school alternative, which is cheaper than before. In that case, they could end up better off.

The effect of the voucher is less complicated for owners. Owners of houses in Community 1 lose because the voucher reduces the rent of their houses. Owners in Community 2 gain. The interesting case is the homeowner, who is both a renter and an owner. For the homeowner as a renter, the voucher has one effect. For the homeowner as an owner, it has the opposite effect. The latter effect dominates, however, because any change in rent is capitalized into the value of the house. Consider, for example, a family that owns a home in the community with good schools. If the family stays in its home and continues to send its children to public schools, nothing has changed--nothing except the value of its home, which is now lower, leaving the family with less wealth when it moves. For a family owning a home in the community with poor schools, the effect is just the opposite. It loses from the voucher as a renter, gains as an owner, and gains overall. The family can still send its children to the same schools as before but now has a more valuable house. 
Table 1

The Effect of a Voucher

\begin{tabular}{l|c|ccc} 
& Community 1 & \multicolumn{3}{|c}{ Community 2 } \\
\cline { 3 - 5 } & & $\begin{array}{c}\text { Children in } \\
\text { Private School }\end{array}$ & $\begin{array}{c}\text { Children in } \\
\text { Public School }\end{array}$ & $\begin{array}{c}\text { Families without } \\
\text { Children }\end{array}$ \\
\hline \multirow{2}{*}{ Renters } & + & + & $+/-$ & - \\
Homeowners & - & + & + & + \\
\hline
\end{tabular}

These results are summarized in Table 1. A plus sign in a cell indicates that the voucher has a positive effect on the welfare of families represented by that cell, and a minus sign indicates a negative effect. For families with children in public schools in Community 2, the effect could be either positive or negative, so the cell representing those families has both signs.

In deriving these results, we have ignored a number of important issues. First, to illustrate the basic effect of the voucher on housing prices, we have made a number of simplifying assumptions about the housing market, the most important of which is that houses in the two communities are identical. Nechyba (2000) has analyzed the more realistic case, in which the housing stock is heterogeneous, but reaches essentially the same conclusions.

Also, we have ignored the net fiscal cost of the voucher. From a taxpayer's perspective, the voucher has a fixed cost and a variable benefit. The fixed cost is the subsidy the state must pay to families who would have enrolled their children in private schools without the voucher. However, because the voucher was half the per-pupil cost of public schools, the fixed cost would have been offset by the tax revenue saved from families induced to switch from public to private schools. The breakeven point would have been a doubling of private school enrollment. We do not know whether this point would have been reached, but it does seem reasonable to conclude 
that the voucher would have had a small fiscal effect, implying that the issue of fiscal cost should not have had an important effect on voting patterns.

The third issue we have ignored is the potential effect of the voucher on public school spending per pupil. Because the voucher would have decreased public school enrollment, it would have also decreased the tax-price of public school spending per pupil and thus increased the demand for that spending. On the other hand, parents switching from public to private schools would have been less likely to support increases in public school spending per pupil. These opposing forces have been analyzed by Rangazas (1995) and by Hoyt and Lee (1998). Based on our reading of this literature, we conclude that it is unlikely that the voucher would have had a negative effect on public school spending per pupil. Again, we conclude that this issue should not have had an important effect on voting patterns.

Finally, we have ignored the peer group effect. Opponents of the voucher argue that the quality of public schools depends crucially on the characteristics of the students who attend them, that good students improve the educational experience of less motivated or able students. They fear that the voucher would cause some of the best students to leave the public schools, decreasing the quality of those schools for other students. Based on the analysis of Epple and Romano (1998), we believe the peer group effect would tend to amplify the housing price changes on which we have focused. In the absence of a voucher, high-quality schools benefit most from a favorable peer group, and so they have the most to lose from a voucher-induced flight of good students to the private sector. Nechyba (2000) finds support for this conclusion. He includes a peer group effect in his simulations and finds that his results are sensitive to the strength of that effect. The greater the association between the peer group effect and family 
income, the larger the difference in mean property values between high- and low-quality school districts, and the greater the impact the voucher has on that difference.

\section{Housing Price Premiums}

To determine whether housing premiums for school districts affected the vote on Proposition 174, we analyzed voting returns on the Proposition for all precincts in Los Angeles County. We first estimated a housing price premium for every school district in the County. To estimate the premium, we collected data on sales of single-family houses that occurred during 1992 or 1993. Our records on each sale included several variables describing the characteristics

of the house; we augmented that data with other variables describing each house's neighborhood and community. Our objective was to use that data to estimate the portion of the sales price of each house that was due to the quality of the school district in which it was located. We proceeded by first constructing two measures of educational quality for each school district. We then regressed the price of houses in our sample on house, neighborhood, and community characteristics and on the measures of school district quality, yielding estimated coefficients for each variable. Finally, we estimated the housing price premium of each school district by multiplying the district quality measures by the estimated coefficients for those measures and then summing the two products.

In 1993, Los Angeles County had 43 unified school districts and 31 elementary school districts. Each elementary district was connected to one of 6 high school districts. The largest district is Los Angeles Unified with nearly 600,000 students, almost half of all public school students in Los Angeles County. The size of the district naturally raises concerns about whether our results would change if we removed it from our sample. To address those concerns, we have 
performed our analysis on a sample including housing sales and precinct returns from all districts in the County and also on a sample excluding sales and returns from Los Angeles Unified. We found the results from the two samples to be quite similar and consequently report only results from the sample without Los Angeles Unified.

Our data on house sales came from the Experian Company (formerly TRW). Each observation is the record of a specific sale of an owner-occupied, single-family home sold during 1992 or 1993 . There are 52,699 observations. Variables describing the physical characteristics of each home include both quantity and quality measures. House size is represented by square footage of living space, number of bathrooms, and lot size or land area. House quality is represented by house age, the number of fireplaces, whether the house has a pool, whether it has a view, and whether it has central air conditioning.

We matched each home in our sample with seven measures of neighborhood and community quality. Four variables describe the census tract in which the house is located. The variables, which are from the 1990 Census of Population and Housing, are percentage of the population age sixty-five or older, percentage of the population below the poverty level, percentage of the population white, and time to work. In addition to the census tract variables, we utilized three other neighborhood indicators: (1) environmental quality, which uses the measure of total suspended particulates from Beron, Murdoch, and Thayer (1998); (2) crime rate, measured at the city level as the FBI index of major crimes; and (3) climate, measured by whether the neighborhood is within five miles of the Pacific Ocean.

Our measures of school district quality are derived from the performance of a district's students on the California Learning Assessment System (CLAS) test. The CLAS test was a

\footnotetext{
${ }^{1}$ Regression results from the sample with Los Angeles Unified are reported in Table A4 in the Appendix.
} 
standardized exam of math and English proficiency administered to all fourth and tenth graders in 1992-93. Student performance was based on a scale that ranged from 1 to 6 , with students scoring a 4 or higher judged to have an "above average" knowledge of the test material. For both fourth and tenth grade scores, we formed a composite score by averaging the percentage achieving a 4 or higher on the math exam with the percentage achieving 4 or higher on the English exam. For the tenth grade score of an elementary school district, we used the tenth grade composite score from the high school district to which the elementary school students next matriculated. The fourth- and tenth-grade composite scores are our two measures of school district quality.

Table A1 in the Appendix lists the definitions, means, and standard deviations of all variables in the housing price regression. Table A2 reports the results of estimating the log of the sale price of each house as a function of these variables, and Table A3 lists housing price premiums for each school district in our sample. The premiums are expressed as percentages of the average premium. For example, the premium for the La Canada school district, purported to be one of the best in Los Angeles County, is 29\%, indicating that a house in that district sold for $29 \%$ more than a house with the same physical and neighborhood characteristics in a district with the average premium. For a house with a sales price of $\$ 230,000$, which is roughly average for our sample, this premium translates into a price difference of about $\$ 67,000$.

This price difference implies a difference in imputed rent, the annual cost of owning and occupying a house. One way to express this rent difference is to calculate the additional mortgage interest and property taxes required by the additional $\$ 67,000$ in value. The Federal Home Mortgage Corporation reported an average mortgage interest rate in 1993 of $7.33 \%$. The property tax rate in California was fixed at $1 \%$ by Proposition 13 . Thus, an additional $\$ 67,000$ in 
the price of a house would have cost a homeowner approximately $\$ 5,600$ more in property taxes and mortgage interest. Because these payments are deductible on state and federal income taxes, the after-tax cost would have been substantially lower. For a family with taxable income between $\$ 40,000$ and $\$ 90,000$, the marginal income tax rate in 1993 was $28 \%$ at the federal level and $9.3 \%$ at the state level, yielding an after-tax cost of approximately $\$ 3,400$.

The model developed in Section 2 suggests that this difference in imputed rent should equal private school tuition. This equality was approximately satisfied. In 1993, Dianda and Corwin (1993) surveyed private schools in California. They found that about 20\% of nonreligious, elementary schools had tuition less than $\$ 2,600$, about 50\% had tuition between $\$ 2,600$ and $\$ 5,000$, and about $20 \%$ of schools had tuition in excess of $\$ 5,000$. For secondary, nonreligious schools, $14 \%$ had tuition less than $\$ 2,600,36 \%$ had tuition between $\$ 2,600$ and $\$ 5,000$, and $50 \%$ had tuition over $\$ 5,000$.

\section{Two Competing Hypotheses}

The capitalization hypothesis developed in Section 2 predicts a negative relationship between housing price premiums and support for the voucher, but there is another explanation for this voting pattern. Many voters may have interpreted the voucher initiative as a referendum on California's public schools. In that case, voters in good school districts would not have favored the voucher because they were relatively satisfied with their public schools. In contrast, voters living in poor school districts were more likely to be dissatisfied with public education and thus more likely to vote in favor of a policy to reform it. Because housing prices reflect school district quality, this referendum hypothesis also predicts a negative relationship between precinct returns and the housing price premium. 
While the referendum and capitalization hypotheses predict the same voting patterns for homeowners, they predict different patterns for renters. The referendum hypothesis implies that renters should have the same voting pattern as homeowners. As we move from precincts in lowpremium districts to precincts in high-premiums districts, the percentage of renters favoring the voucher should decrease just as should the percentage of homeowners favoring the voucher. The capitalization hypothesis implies that the voting pattern of renters should differ from that of homeowners. As Table 1 illustrates, the pattern is also more complex. Renters located in highquality school districts should favor the voucher initiative because it will decrease their rents. In low-quality districts, some renters should favor the voucher, and some should oppose it. Renters without school children should oppose the voucher, because it would increase their rent. Renters with children in public school should also oppose the voucher if they continue to send their children to public school after the voucher is implemented. In contrast, renters who send their children to private school should favor the voucher. Thus, as we move from precincts with low premiums to precincts with high premiums, the percentage of renters favoring the voucher may either rise or stay the same, depending on how many renters enroll their children in private school. This number is relatively small, however, so we conclude that the percentage of renters favoring the voucher should increase as we move from low-premium precincts to high-premium precincts. This pattern is very different from that for homeowners, in which the percentage voting yes should fall as we move from low-premium to high-premium precincts.

We do not have data on how renters and homeowners voted, but we do have data on the percentage of renters and homeowners in each precinct and on their characteristics, data which permit a test of the differing predictions of the two hypotheses. To construct this test, we specify 
two separate equations for the percentage of yes votes in a precinct, one equation for homeowners and one for renters. The equation for homeowners is

$$
Y_{i j}^{h}=\alpha^{h}+X_{i j}^{h} \beta^{h}+P_{j} \lambda^{h}+v_{i j}^{h},
$$

where $Y_{i j}^{h}$ is the percentage of yes votes on the voucher initiative for homeowners in precinct $i$ and district $j, X_{i j}^{h}$ is a vector of characteristics of homeowners in precinct $i, P_{j}$ is the housing price premium associated with district $j, v_{i j}^{h}$ is a random disturbance term, and $\alpha^{h}, \beta^{h}$ and $\lambda^{h}$ are unknown parameters. Under either the capitalization or referendum hypotheses, $\lambda^{h}$ should be less than zero.

The equation for renters is

$$
Y_{i j}^{r}=\alpha^{r}+X_{i j}^{r} \beta^{r}+P_{j} \lambda^{r}+v_{i j}^{r},
$$

where $Y_{i j}^{r}$ is the percentage of yes votes on the voucher initiative for renters in precinct $i$ and district $j, X_{i j}^{r}$ is a vector of characteristics of renters in precinct $i, \alpha^{r}, \beta^{r}$ and $\lambda^{r}$ are unknown parameters, and $v_{i j}^{r}$ is a random disturbance term. According to the referendum hypothesis, renters should behave just as homeowners, implying that $\lambda^{r}$ should be equal to $\lambda^{h}$, which is negative. According to the capitalization hypothesis, however, $\lambda^{r}$ should be non-negative.

The total vote in a precinct is the sum of the votes of renters and owners. Let $Y_{i j}$ be the percentage of all voters in precinct $i$ district $j$ that vote yes, and let $W_{i j}$ be the percentage of voters in the precinct who are renters. Then,

$$
Y_{i j}=W_{i j} Y_{i j}^{r}+\left(1-W_{i j}\right) Y_{i j}^{h} .
$$

Using Equations (4) and (5), Equation (6) can be written as 


$$
\begin{aligned}
Y_{i j}= & \alpha^{h}+W_{i j}\left(\alpha^{r}-\alpha^{h}\right)+W_{i j} X_{i j}^{r} \beta^{r}+\left(1-W_{i j}\right) X_{i j}^{h} \beta^{h} \\
& +P_{j} \lambda^{h}+W_{i j} P_{j}\left(\lambda^{r}-\lambda^{h}\right)+v_{i j},
\end{aligned}
$$

where $v_{i j}$ is a random disturbance term.

Using estimates from the regression in Equation (7), we could test whether the coefficients from the renter equation are equal to the coefficients from the homeowner equation, which would be a general test of the referendum hypothesis. However, it seems more reasonable to us to focus on a specific test involving the coefficient on the term interacting the percentage of renters with the housing price premium. Under the referendum hypothesis, the coefficient should be zero. Moving from precincts with low premiums to precincts with high premiums should have the same negative effect on the vote of renters and homeowners. Under the capitalization hypothesis, the coefficient should be positive, however, and greater in absolute value than $\lambda^{h}$. That is, $\lambda^{r}$ should be non-negative, implying that $\left(\lambda^{r}-\lambda^{h}\right)$ should be greater than $-\lambda^{h}$. In this case, as we move from precincts with low premiums to precincts with high premiums, the vote in favor of the initiative should decrease among homeowners and increase among renters.

\section{Precinct Returns}

In the 1993 election, Los Angeles County had 3,786 precincts, 1,612 of which were in the Los Angeles Unified School District. Excluding that district left us with a sample of 2,174 precincts. Voting outcomes on Propostion 174 varied widely across those precincts. In this section, we report results from regressing the percentage of voters in each precinct favoring the Proposition on various precinct characteristics.

We obtained precinct returns from the Los Angeles County Registrar. This database listed the census tract in which each precinct is located, allowing us to use data from the 
Table 2

Precinct Socio-Economic Characteristics

\begin{tabular}{l|cc} 
Variable & Mean & $\begin{array}{c}\text { Standard } \\
\text { Deviation }\end{array}$ \\
\hline $\begin{array}{l}\text { Percentage of Renters } \\
\begin{array}{c}\text { Characteristics of Homeowners } \\
\text { Mean Household Income of Homeowners } \\
\quad \text { (thousands of dollars) }\end{array}\end{array}$ & 37.23 & 22.94 \\
$\begin{array}{l}\text { Percentage of Homeowners 65 or Older } \\
\text { Percentage of Homeowners White }\end{array}$ & 63.14 & 29.41 \\
$\begin{array}{c}\text { Characteristics of Renters } \\
\text { Mean Household Income of Renters } \\
\quad \text { thousands of dollars) }\end{array}$ & 65.95 & 10.32 \\
$\quad \begin{array}{l}\text { Percentage of Renters 65 or Older } \\
\text { Percentage of Renters White }\end{array}$ & 38.90 & 25.36 \\
\hline
\end{tabular}

1990 Census of Population and Housing. At the tract level, the Census provides a limited number of variables that are broken down separately for homeowners and renters. We used these variables to describe the characteristics of renters and homeowners in each precinct. These variables constitute the $X_{i j}^{r}$ and $X_{i j}^{h}$ vectors in Equation (7). Means and standard deviations of these variables are listed in Table 2.

These variables measure the characteristics of all households, not just those who voted on the voucher initiative. This distinction is particularly important for our measure of the percentage of renters, $W_{i j}$. Using data from the U.S. General Social Survey, DiPasquale and Glaeser (1999) find that homeowners are more likely to vote in local elections than are renters. The participation rate of renters is $52 \%$ as compared to $77 \%$ for homeowners. If these 
participation rates were to hold in a precinct where $37 \%$ of households rent, which is average for our sample, only $28 \%$ of voters would be renters. Thus, our measure of the percentage of voters who are renters would overstate the true percentage by about $30 \%$. If this percentage were to hold throughout our sample, our estimate of $\left(\lambda^{r}-\lambda^{h}\right)$, the coefficient on the term interacting percentage renters with the school district premium, would be biased downward by $30 \%$.

The distinction between voters and precinct residents has another important implication. Because we have data on residents, not voters, the precinct returns are best viewed as a sample of opinion from a population described by the Census variables, and the percentage voting yes as an estimate of the percentage of that population favoring the Proposition. Assuming this is a random sample, the variance of the estimate is $p(1-p) / m$, where $p$ is the percentage of the population favoring the Proposition and $m$ is the number of voters. Because $p$ and $m$ vary across precincts, a regression of percentage voting yes on precinct characteristics has a heteroscedastic error term.

A second econometric issue concerns precincts in the same school district. There surely are factors common to all precincts in a district that may influence the vote on Proposition 174 but are not observed by us. As a consequence, the error term in the precinct voting regression is likely to be correlated among precincts in the same district. Moulton (1986) has shown that this group-wise dependence can lead to a downward bias on standard errors for certain coefficient estimates, namely, coefficients for variables that are constant within groups of observations. A school district's housing price premium is a prime example, because it is constant for all precincts in the same district.

To address both heteroscedasticity and group-wise dependence, we used generalized least squares. We applied applied ordinary least squares to estimate the percentage favoring 
Table 3

Generalized Least Squares Coefficient Estimates: Basic Model

\begin{tabular}{l|cc} 
Variable & Coefficient & Standard Error \\
\hline $\begin{array}{l}\text { Housing Price Premium } \\
\begin{array}{l}\text { Variables Interacted with Percentage of Homeowners } \\
\text { Household Income of Homeowners }\end{array}\end{array}$ & -0.385 & 0.044 \\
$\begin{array}{l}\text { Percentage of Homeowners 65 or Older } \\
\text { Percentage of Homeowners White }\end{array}$ & -0.114 & 0.001 \\
$\begin{array}{l}\text { Variables Interacted with Percentage of Renters } \\
\text { Household Income of Renters }\end{array}$ & 0.213 & 0.022 \\
$\begin{array}{l}\text { Percentage of Renters 65 or Older } \\
\text { Percentage of Renters White }\end{array}$ & -0.016 & 0.005 \\
Housing Price Premium & -0.090 & 0.037 \\
Percentage of Renters & 0.089 & 0.021 \\
Constant & 0.223 & 0.057 \\
\hline
\end{tabular}

Proposition 174 in a precinct as a function of the precinct characteristics. Using the residuals from this regression and the formula for the variance of precinct returns, we then estimated the covariance matrix of the error terms and applied this matrix in a generalized least squares regression. For details, see Baltagi and Griffin (1998), Baltagi (1995), and Randolph (1988).

Table 3 shows the results from the generalized least squares estimation of Equation (7). The estimate of the coefficient on the housing price premium is negative and significant, consistent with both the referendum and capitalization hypotheses. In contrast, the interaction term between the housing price premium and the percentage of renters is positive and significant, 
which is inconsistent with the referendum hypothesis, but consistent with the capitalization hypothesis. The capitalization hypothesis implies something stronger about this coefficient. It implies that the coefficient should be larger than the absolute value of the coefficient on the housing price premium, an inequality that is not satisfied by the coefficient estimates. However, as we have pointed out above, the coefficient on the interaction term is probably biased downward because of the different voting participation rates of homeowners and renters.

Taken together, the coefficient on the housing price premium and the coefficient on the interaction term imply the housing price premium had a relatively large effect on precinct returns. Consider, for example, a precinct in which $37 \%$ of the households are renters, a percentage that is average for our sample. For such a precinct, our estimated model predicts that an increase in the school district premium from $0 \%$ to $30 \%$ would decrease the vote for Proposition 174 by about 9 percentage points.

In the regression reported in Table 3, we have included only those variables for which we have data separately for homeowners and renters. While this condition is consistent with our underlying test of the referendum and capitalization hypotheses, it does exclude a number of variables that are likely to affect the vote on the voucher initiative. To test the sensitivity of our results, we have also re-estimated our regressions with three of these variables included. The first was the percentage of students enrolled in private school, which we obtained from the Census. This variable should have a positive effect on the percentage voting in favor of the voucher. The second was the percentage of employed persons sixteen years or older who work in educational services, which we take to be a proxy for the percentage of residents who are public school teachers. We included this variable because public school teachers are often vocal opponents of the voucher as evidenced by the $\$ 12.5$ million the California Teachers Association 
Table 4

Generalized Least Squares Coefficient Estimates: Expanded Model

\begin{tabular}{|c|c|c|}
\hline Variable & Coefficient & Standard Error \\
\hline Housing Price Premium & -0.313 & 0.028 \\
\hline $\begin{array}{l}\text { Variables Interacted with Percentage Homeowners } \\
\text { Household Income of Homeowners }\end{array}$ & -0.008 & 0.0007 \\
\hline Percentage of Homeowners 65 or Older & -0.101 & 0.020 \\
\hline Percentage of Homeowners White & 0.102 & 0.014 \\
\hline $\begin{array}{l}\text { Variables Interacted with Percentage Renters } \\
\text { Household Income of Renters }\end{array}$ & -0.023 & 0.004 \\
\hline Percentage of Renters 65 or Older & -0.157 & 0.034 \\
\hline Percentage of Renters White & 0.022 & 0.020 \\
\hline Housing Price Premium & 0.143 & 0.052 \\
\hline $\begin{array}{l}\text { Other Control Variables } \\
\quad \text { Percentage of Voters Republican }\end{array}$ & 0.250 & 0.017 \\
\hline Percentage Employed in Education & -0.149 & 0.030 \\
\hline Percentage with Children in Private School & 0.105 & 0.016 \\
\hline Percentage of Renters & 0.153 & 0.019 \\
\hline Constant & 0.186 & 0.011 \\
\hline
\end{tabular}

contributed to opponents of Proposition $174 .^{-}$The third variable was the percentage of registered Republican voters in a precinct. Because the voucher has been a mainstay of conservative political philosophy, this variable should have a positive effect on the percentage favoring the voucher. The results from adding these three variables are given in Table 4.

2 Los Angeles Times, November 2, 1993, page A-1. 
The inclusion of these three variables has a significant effect on the regression results. The coefficients on all three have the expected sign and are statistically significant. The coefficient on the income of homeowners is now negative, a result which is undoubtedly due to the positive correlation between income and private school enrollment and between income and Republican Party registration. Note, however, that the basic results are unchanged. The coefficient on the school district premium is still negative and significant, and the coefficient on the term interacting the premium with percentage of renters is still positive and significant.

\section{Conclusion}

Our results clearly show that voters in good public school districts were significantly less likely to vote in favor of the voucher initiative. It is less clear whether this voting pattern resulted because voters interpreted the voucher as a referendum on their local public schools or because homeowners in good school districts saw the voucher as a threat to their property values. Our empirical work tends to support the second explanation.

Our results also suggest that the capitalization of school district quality played a role in the outcome of Proposition 174. Holding all other variables constant, we estimated that the vote in favor of Proposition 174 was 9 percentage points less in a district with a premium $30 \%$ above the average than in a district with the average premium. This conclusion carries a message for future attempts to implement the voucher. Voucher proposals are more likely to be successful if they do not threaten property values in good school districts. One possibility is a voucher targeted to low-income parents. This is not a new idea, though it is usually motivated as a way to help families trapped in substandard, inner-city schools. Our research suggests that such proposals may also make vouchers less threatening to wealthy homeowners. 


\section{References}

Baltagi, Badi H., and James H. Griffin, "A Generalized Error Component Model with Heteroscedastic Disturbances," International Economic Review 29(4), 745-753 (1998).

Baltagi, Badi H., Econometric Analysis of Panel Data. John Wiley and Sons Inc., New York, NY (1995).

Beron, Kurt J., James C. Murdoch, and Mark A. Thayer, "Improving Visibility Benefit Estimates from Hedonic Models," Report of the South Coast Air Quality Management District, June (1998).

DiPasquale, Denise, and Edward L. Glaeser, "Incentives and Social Capital: Are Homeowners Better Citizens?," Journal of Urban Economics 45, 354-384 (1999).

Dianda, Marcella R., and Ronald G. Corwin, "What a Voucher Could Buy: A Survey of California's Private Schools," Southwest Regional Laboratory, Los Alamitos, CA (1993).

Epple, Dennis, and Richard E. Romano, "Competition Between Private and Public Schools, Vouchers, and Peer-Group Effects," American Economic Review, 88, 33-62 (1998).

Hoyt, William H., and Kangoh Lee, "Educational Vouchers, Welfare Effects, and Voting," Journal of Public Economics, 69, 211-228 (1998).

Moulton, Brent R., "Random Group Effects and the Precision of Regression Estimates," Journal of Econometrics 32, 385-397 (1986).

Nechyba, Thomas J., "Mobility, Targeting, and Private School Vouchers," American Economic Review 90,130-146 (2000).

Randolph, William C., "A Transformation for Heteroscedastic Error Components Regression Models," Economic Letters 27, 349-354 (1988).

Rangazas, Peter, "Vouchers and Voting: An Initial Estimate Based on the Median Voter Model," Public Choice 82, 261-279 (1995). 


\section{Appendix}

Table A1

\begin{tabular}{|c|c|c|}
\hline \multicolumn{3}{|c|}{ Variables in Housing Price Regression } \\
\hline Variable & Mean & $\begin{array}{l}\text { Standard } \\
\text { Deviation }\end{array}$ \\
\hline \multicolumn{3}{|l|}{ Structural Characteristics } \\
\hline Lot Area & 9.65 & 19.86 \\
\hline (thousands of square feet) & & \\
\hline Interior Living Space & 1.61 & 0.76 \\
\hline (thousands of square feet) & & \\
\hline Number of Bathrooms & 1.84 & 0.79 \\
\hline Age of Home & 37.08 & 18.06 \\
\hline $\begin{array}{l}\text { Central Air Conditioning } \\
\quad(\text { yes }=1, \text { no=0) }\end{array}$ & 0.27 & 0.44 \\
\hline Number of Fireplaces & 0.66 & 0.63 \\
\hline Pool & 0.19 & 0.39 \\
\hline$($ yes $=1, n o=0)$ & & \\
\hline View & 0.03 & 0.17 \\
\hline$($ yes $=1, n o=0)$ & & \\
\hline \multicolumn{3}{|l|}{ Neighborhood Characteristics } \\
\hline Percentage in Census Tract Above 65 Years Old & 11.48 & 5.39 \\
\hline Percentage in Census Tract Below Poverty Level & 8.35 & 6.49 \\
\hline Percentage in Census Tract White & 60.26 & 24.70 \\
\hline Per Capita FBI Crime Index & 66.05 & 13.92 \\
\hline $\begin{array}{l}\text { Within Five Miles of Pacific Ocean } \\
\quad(y e s=1, n o=0)\end{array}$ & 0.03 & 0.16 \\
\hline $\begin{array}{l}\text { Time to Work } \\
\quad \text { (Minutes) }\end{array}$ & 29.70 & 5.34 \\
\hline $\begin{array}{l}\text { Annual Average of Total Suspended Particulates } \\
\quad \text { (Parts Per Million) }\end{array}$ & 70.09 & 7.19 \\
\hline Percentage of Fourth Graders Above Average on CLAS & 19.70 & 8.09 \\
\hline Percentage of Tenth Graders Above Average on CLAS & 17.98 & 9.31 \\
\hline Sale Price & $\$ 229,349$ & $\$ 199,250$ \\
\hline
\end{tabular}


Table A2

Estimated Hedonic Regression:

Dependent Variable $=$ Ln $($ Sale Price $)$

\begin{tabular}{l|r} 
& \\
Variables & Coefficient* \\
\hline & \\
Structural Characteristics & 0.001 \\
Lot Area & 0.304 \\
Interior Living Space & 0.041 \\
Number of Bathrooms & -0.002 \\
Age of Home & 0.045 \\
Central Air Conditioning & 0.044 \\
Number of Fireplaces & 0.057 \\
Pool & 0.019 \\
View & \\
Neighborhood Characteristics & \\
Percentage in Census Tract Above 65 Years Old & 0.001 \\
Percentage in Census Tract Below Poverty Level & -0.006 \\
Percentage in Census Tract White & 0.003 \\
Per Capita FBI Crime Index & -0.001 \\
Time to Work in Minutes & -0.001 \\
Within Five Miles of Pacific Ocean & 0.165 \\
Annual Average of Total Suspended Particulates & -0.001 \\
Percentage of Fourth Grade Students Above Average on CLAS & 0.007 \\
Percentage of Tenth Grade Students Above Average on CLAS & 0.009 \\
& \\
Constant & 11.350 \\
Number of Observations & \\
& 52,699 \\
\hline Not Allcoting & \\
\hline
\end{tabular}

* Note: All coefficients are significantly different from zero at the 5\% level. 
Table A3

\section{School District Premiums}

Unified Districts

ABC
Arcadia
Azusa
Baldwin Park
Bassett
Bellflower
Beverly Hills
Bonita
Burbank
Charter Oak
Claremont
Compton
Covina Valley
Culver City
Downey
Duarte
El Rancho
El Segundo
Glendale
Glendora
Hacienda-La Puente
Inglewood
La Canada
Las Virgenes
Long Beach
Lynwood
Monrovia
Montebello
Norwalk-La Mirada
Palos Verdes Peninsula
Paramount
Pasadena
Pomona
Rowland
San Gabriel
San Marino
Santa Monica-Malibu
South Pasadena
Temple City
Torrance
Walnut Valley
West Covina

Elementary Districts

\begin{tabular}{|c|c|c|}
\hline $14.12 \%$ & Alhambra & $-0.68 \%$ \\
\hline $29.64 \%$ & Castaic Union & $2.84 \%$ \\
\hline$-14.07 \%$ & East Whittier City & $-3.52 \%$ \\
\hline$-16.16 \%$ & Eastside Union & $-12.81 \%$ \\
\hline$-17.80 \%$ & El Monte City & $-10.45 \%$ \\
\hline$-5.94 \%$ & Garvey & $-3.38 \%$ \\
\hline $25.96 \%$ & Hawthorne & $-15.68 \%$ \\
\hline $3.20 \%$ & Hermosa Beach City & $25.56 \%$ \\
\hline $0.69 \%$ & Hughes-Elizabeth Lakes & $-8.41 \%$ \\
\hline$-10.89 \%$ & Keppel Union & $-13.48 \%$ \\
\hline $5.24 \%$ & Lancaster & $-9.42 \%$ \\
\hline$-22.26 \%$ & Lawndale & $-16.02 \%$ \\
\hline $4.23 \%$ & Lennox & $-18.05 \%$ \\
\hline $11.45 \%$ & Little Lake City & $-7.58 \%$ \\
\hline$-3.76 \%$ & Los Nietos & $-7.58 \%$ \\
\hline$-4.03 \%$ & Lowell Joint & $13.99 \%$ \\
\hline$-16.26 \%$ & Manhattan Beach City & $21.50 \%$ \\
\hline $14.56 \%$ & Mountain View & $-13.16 \%$ \\
\hline $1.37 \%$ & Newhall & $6.90 \%$ \\
\hline $11.37 \%$ & Palmdale & $-5.70 \%$ \\
\hline$-2.00 \%$ & Redondo Beach City & $20.48 \%$ \\
\hline$-14.82 \%$ & Rosemead & $-9.10 \%$ \\
\hline $28.84 \%$ & Saugus Union & $4.19 \%$ \\
\hline $16.42 \%$ & Soledad Aqua Dolce & $-6.72 \%$ \\
\hline$-9.52 \%$ & South Whittier & $-6.23 \%$ \\
\hline$-14.19 \%$ & Sulphur Springs & $5.21 \%$ \\
\hline$-8.95 \%$ & Valle Lindo & $-13.84 \%$ \\
\hline$-13.53 \%$ & Westside & $-4.69 \%$ \\
\hline$-5.90 \%$ & Whittier City & $-8.59 \%$ \\
\hline $35.76 \%$ & Wilsona & $-9.08 \%$ \\
\hline$-9.88 \%$ & Wiseburn & $-7.90 \%$ \\
\hline$-4.08 \%$ & & \\
\hline$-14.68 \%$ & & \\
\hline$-3.96 \%$ & & \\
\hline$-2.71 \%$ & & \\
\hline $38.11 \%$ & & \\
\hline $18.76 \%$ & & \\
\hline $23.60 \%$ & & \\
\hline $16.02 \%$ & & \\
\hline $15.26 \%$ & & \\
\hline $23.80 \%$ & & \\
\hline$-11.61 \%$ & & \\
\hline
\end{tabular}




\section{Table A4}

Regression Results with Los Angeles Unified

\begin{tabular}{|c|c|c|}
\hline Variable & $\begin{array}{l}\text { Coefficient } \\
\text { (St. Error) } \\
\end{array}$ & $\begin{array}{l}\text { Coefficient } \\
\text { (St. Error) } \\
\end{array}$ \\
\hline Housing Price Premium & $\begin{array}{l}-0.336 \\
(0.050)\end{array}$ & $\begin{array}{l}-0.383 \\
(0.030)\end{array}$ \\
\hline Variables Interacted with Percentage Homeowners & & \\
\hline $\begin{array}{l}\text { Household Income of Homeowners } \\
\text { (tens of thousands of dollars) }\end{array}$ & $\begin{array}{l}-0.003 \\
(0.0004)\end{array}$ & $\begin{array}{l}-0.004 \\
(0.0005)\end{array}$ \\
\hline Percentage of Homeowners 65 or Older & $\begin{array}{l}-0.27 \\
(0.020)\end{array}$ & $\begin{array}{l}-0.125 \\
(0.017)\end{array}$ \\
\hline Percentage of Homeowners White & $\begin{array}{c}0.300 \\
(0.010)\end{array}$ & $\begin{array}{c}0.053 \\
(0.010)\end{array}$ \\
\hline Variables Interacted with Percentage Renters & & \\
\hline $\begin{array}{l}\text { Household Income of Renters } \\
\text { (tens of thousands of dollars) }\end{array}$ & $\begin{array}{l}-0.023 \\
(0.004)\end{array}$ & $\begin{array}{l}-0.026 \\
(0.003)\end{array}$ \\
\hline Percentage of Renters 65 or Older & $\begin{array}{l}-0.207 \\
(0.026)\end{array}$ & $\begin{array}{l}-0.225 \\
(0.022)\end{array}$ \\
\hline Percentage of Renters White & $\begin{array}{c}0.041 \\
(0.013)\end{array}$ & $\begin{array}{l}-0.005 \\
(0.010)\end{array}$ \\
\hline Housing Price Premium & $\begin{array}{c}0.270 \\
(0.050)\end{array}$ & $\begin{array}{c}0.240 \\
(0.039)\end{array}$ \\
\hline Other Control Variables & & \\
\hline Percentage of Voters Republican & - & $\begin{array}{c}0.495 \\
(0.012)\end{array}$ \\
\hline Percentage Employed in Education & - & $\begin{array}{l}-0.217 \\
(0.023)\end{array}$ \\
\hline Percentage with Children in Private School & - & $\begin{array}{c}0.053 \\
(0.011)\end{array}$ \\
\hline Percentage Renters & $\begin{array}{c}0.143 \\
(0.015)\end{array}$ & $\begin{array}{c}0.116 \\
(0.012)\end{array}$ \\
\hline Constant & $\begin{array}{l}0.243 \\
(0.010)\end{array}$ & $\begin{array}{l}0.170 \\
(0.008)\end{array}$ \\
\hline
\end{tabular}

